\title{
189. CAREX CASTROVIEJOI LUCEÑO \& JIMÉNEZ MEJÍAS (CYPERACEAE), A NEW SPECIES FROM NORTH GREEK MOUNTAINS
}

\author{
Pedro JIMÉNEZ-MEJÍAS* \& Modesto LUCEÑO
}

Recibido el 6 de julio de 2009, aceptado para su publicación el 8 de julio de 2009

Publicado "on line" en julio de 2009

Carex castroviejoi Luceño \& Jiménez Mejías (Cyperaceae), una especie nueva de las montañas del norte de Grecia

Palabras clave. Grupo de Carex flava, Grecia, Montes Pindo, serpentinas, endemismo.

Key words. Carex flava group, Greece, Pindus mountains, serpentines, endemic.

Carex castroviejoi Luceño \& Jiménez Mejías, sp. nov. (fig. 1-2)

- C. lepidocarpa sensu Chater (1980), Flora Europaea 5: 310, p.p., non Tausch

- C. lepidocarpa sensu Strid \& Kit Tan (1991), Mountain Flora of Greece, 2: 853-854, non Tausch

Holotypus. Greece, Epirus, Ioannina, Parque Valia Kalnta, 1698 m, 39 $52^{\prime}$ N $21^{\circ}$ $11^{\prime}$ E, taludes pedregosos en dominio del Pinus heldreichii y Fagus sylvatica, 29.VI.2008, M. Luceño (3108ML), P. Vargas \& F.J. Fernández [UPOS (3442)]. Isotypus: UPOS.

Speciei Carex lepidocarpa Tausch., similis a qua praesertim, spica mascula late fusiformis, differt.

Perennial, cespitose. Stems 7-40 cm length, trigonous, smooth, erect or slightly curved. Leaves 0.9-3 mm wide, usually shorter than stems, flat, light green; ligule short, slightly protruding beyond the sheath apex, truncate to rounded, scarious, absent from the cauline leaves; anteligule 1-2 mm, rounded; basal leaf sheaths unconspicuous, weak, light brown. Lowest bract $1-6 \mathrm{~cm} \times 0.5-3 \mathrm{~mm}$, as long as or a bit longer than inflorescence, shortly leaf- like, sometimes bristle-like. Male spike 1, 7-20 $\times 3-3.5(4.2) \mathrm{mm}$, terminal, widely fusiform to elliptical, with a peduncle 1-15(20) $\mathrm{mm}$; female spikes 1-3, the lowest one 7-10 mm long, generally clustered at stem apex, sessile or short-peduncled, erect, sometimes with a long-peduncled basilar spike, rarely some of them androgynous. Male glumes oval, subacute to obtuse, entirely brown, with a lighter middle nerve; female glumes oval, subacute to obtuse, brown, with a lighter middle nerve and sometimes an inconspicuous scarious margin. Stigmata 3. Utricles 3.2-4.5(4.8) × 0.9-1.5 mm, green to dark brown, those from the lower half of the spike strongly deflexed, those from the upper half deflexed to patent, the apical ones patent to erect-patent, elliptical, trigonous, plurinerved, gradually attenuated into a 1.2$2.2(2.5) \mathrm{mm}$, deflexed $\left(30-40^{\circ}\right.$ in reference to utricle body), bidentate or bifid, smooth beak. Achenes 1.5-1.8 × $1 \mathrm{~mm}$, narrowly obovate, trigonous.

Etymology. This new species is named in honour of our dear friend and mentor Dr. Santiago Castroviejo Bolíbar, main architect of Flora iberica, the most important work in the Spanish botanical history. 


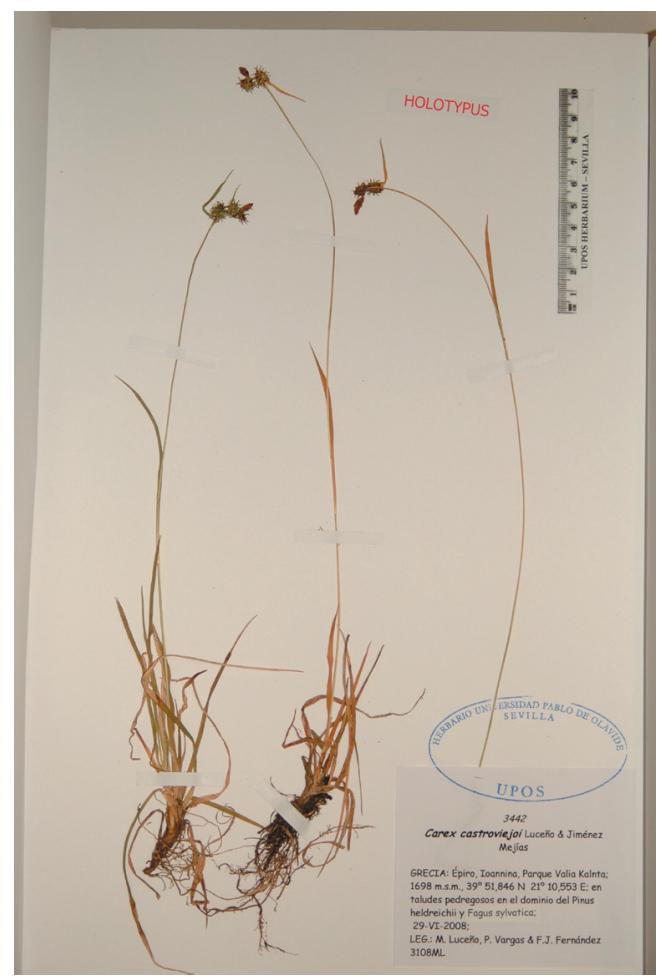

Figure 1. Holotype of Carex castroviejoi Luceño \& Jiménez Mejías

Ecology. Boggy soils over ophiolitic rocks, in montane forests of Pindus range, North Greece.

Distribution. Endemic from North Greece, Epirus and West Macedonia regions (fig. 3). In addition to type materials, we studied plants from the following stations:

Studied materials (paratypi): Greece. Epirus, Ioannina, Milia, Valia Kalnta Nacional Park, 1513 m, 39 $51^{\circ} \mathrm{N} 21^{\circ} 12^{\prime} \mathrm{E}$, arroyos, prados turbosos sobre serpentinas, 28.VI.2008, M. Luceño (2008ML), P. Vargas \& F.J. Fernández (ATH, E, M, MA, MGC, NY, TAU, UPOS); N Pindhos, Katara Pass, flushes on the $\mathrm{N}$ side at $1600 \mathrm{~m}$ with Blysmus and $C$. echinata, on serpentine substrate, 5-VII-1988,

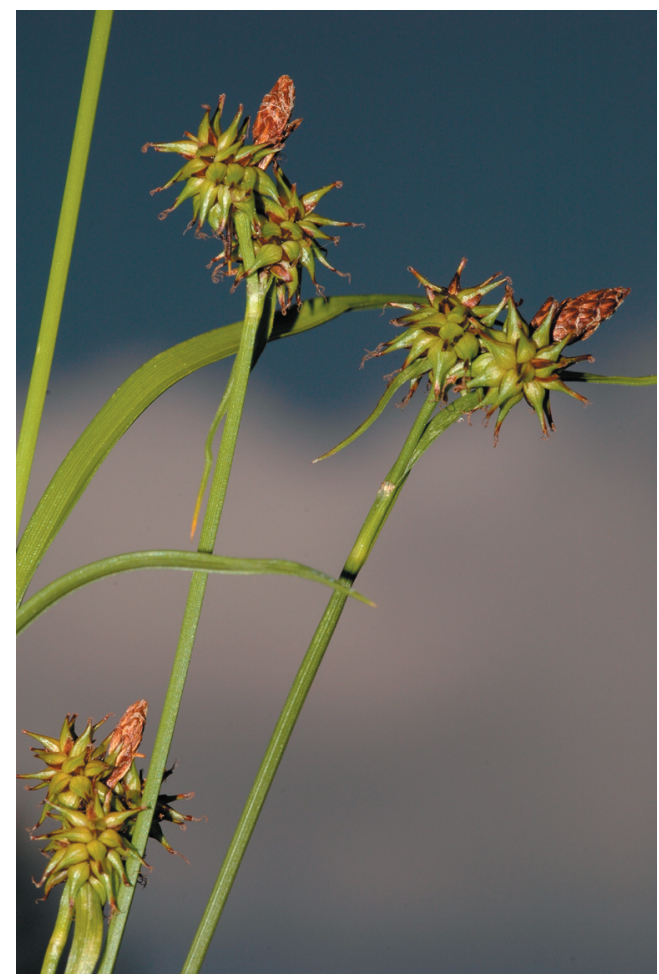

Figure 2. C. castroviejoi specimen from type locality.

A.J. Richards (BM, RNG); Pindhus, Katara Pass $8 \mathrm{~km}$ east of Metsovon, $1650 \mathrm{~m}$, flushes on serpentine, N of top of pass, 30-VI-1985, A.J. Richards \& G. Chaytor (BM, with C. viridula s.str.); Pindhus Mts, W slopes below Mt. Smolikas, 6000 ft., 26-VII-1961, Cambridge University Expedition (K); Konitsa, Vasilitsa ski resort, $1580 \mathrm{~m}$, turberas sobre serpentinas, 12-VII-2004, P. Vargas (281PV04) (UPOS).

West Macedonia, Distr. Grevena, Montes Pindhus, in declivibus boreali orientalibus montis Aphtia, in valle Arkudolaka (Valea Kalda) ditiones pagi Perivoli, substr. serpent., 1700-2100 m, 30,31-VI-1957, K.H. Rechinger $18442(\mathrm{~K})$.

Carex castroviejoi is included in C. flava group (Sect. Ceratocystis), a taxonomically 


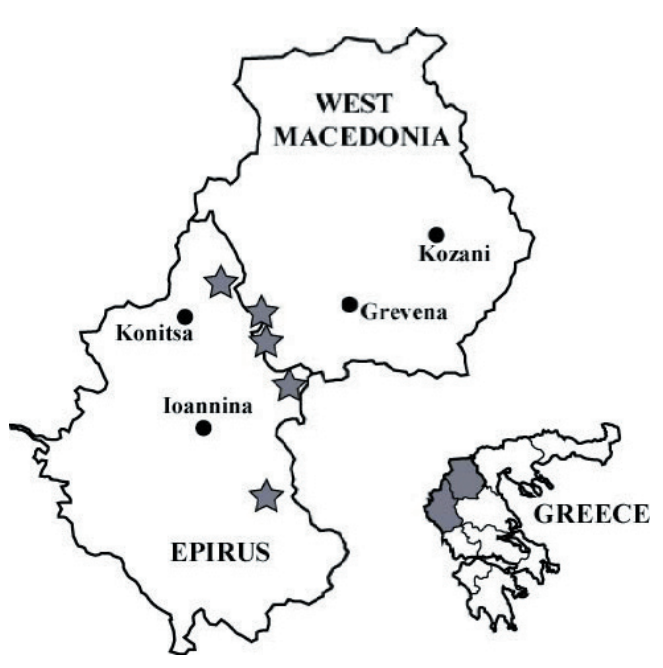

Figure 3. Distribution map including studied populations (represented by star symbols).

difficult complex showing poorly differenciated morphological boundaries and frequent hybridization processes. Four species have been widely accepted in Europe (C. demissa Hornem., C. flava L. s.str., C. lepidocarpa Tausch. y C. viridula Michx. s.str.); the high mountain dwarf forms from Iberian Peninsula, Corse and Alps were included in Flora Europaea under C. nevadensis Boiss. \& Reuter (cf. Chater, 1980, Flora Europaea 5: 310 ), although it is now well stablished that this group is a heterogeneous set of different taxa (Jiménez-Mejías \& Luceño, in preparation). Within this complex two groups of plants may be easily distinguished from a morphological point of view: plants with straight and patent utricles ( C. demissa and C. viridula s.str.) and plants with bent utricles, at least the lower ones from each spike deflexed (C. flava s.str., $C$. lepidocarpa and most of the high mountains forms). Carex castroviejoi should be within this latter group and, in fact Chater (1980, Flora Europaea, 5:310) considered these plants under C. lepidocarpa. Morphological, karyological and molecular studies (Jiménez-Mejías \&
Luceño, in preparation) strongly supported the taxonomic autonomy of $C$. castroviejoi from the remaining members of Carex sect. Ceratocystis. Morphological affinity to C. lepidocarpa could be the result of a convergence phenomenon, since our phylogenetic studies show $C$. castroviejoi as an independent and isolated lineage, not closely related to C. lepidocarpa.

The following key helps to distinguish the bent-beaked taxa of $C$. flava group from the Mediterranean Basin.

1. Male spike 7-20 × 3-3.5(4.2) $\mathrm{mm}$, widely fusiform to elliptical; utricle beak smooth

\section{C. castroviejoi}

- Male spike up to $3 \mathrm{~mm}$ wide, terete, linear or narrowly fusiform; utricle beak smooth or scabrid

2. Utricles dark brown, at least in the upper half, (1.5)2.2-3(3.1) $\mathrm{mm}$ long; lowest bract setaceous or shortly leaf-like, up to $1.5 \mathrm{~mm}$ wide on middle part; apical utricles of each spike erect

C. lepidocarpa subsp. nevadensis

- Utricles green, yellow or light brown, longer than $3 \mathrm{~mm}$; lowest bract leaf-like, wider than $1.5 \mathrm{~mm}$ on middle part; apical utricles of each spike erect to patent

3

3. At least some utricles from the upper half of the spike with a deflexed beak; female spikes oblong to subglobose; male spike usually pedunculate..

C. lepidocarpa subsp. lepidocarpa

- Utricles form the upper half of the spike with erect-patent beaks; female spikes subglobose; male spike sessile.

C. flava s.str.

ACKNOWLEDGEMENTS. The authors wish to thank curators of $\mathrm{BM}, \mathrm{K}$ and $\mathrm{RNG}$ herbaria for providing facilities in the study of materials, F.J. Fernández for technical support, Dr. P. Vargas for kindly collecting materials, and Dr. S. Martín-Bravo and Dr. B. Cabezudo for their critical comments on the manuscript.

Adress of the authors. Department of Molecular Biology and Biochemical engineering. Pablo de Olavide University. Ctra. de Utrera, km. 1. 41013Seville-Spain.

*Corresponding author: pjimmej@upo.es 